\title{
DAMAGE IN THE GREYMOUTH AREA
}

\author{
P. D. Anderson* F. R. Smith* F. Quinn**
}

\section{Location}

The borough of Creymouth, at the mouth the the Grey iiver on the west coust, is $90 \mathrm{~km}$ solutl rest of Inungahua Junction, and thus aproxinately $100 \mathrm{~km}$ from the instrumental epicentre of the main earthrabe shock of $5.24 \mathrm{a}$.m. on Nay 24, 1968,

\section{Subsoil conditions}

The comercial area of the town is founcled on allivial silts ind clays orifinating from the nearby Grey River, and overlying sand strata and rock outcrops from the adjacent hill.s。

The extremities of the commercial zone are from the south bank of the Grey River to approximately $1 \frac{1}{2}$ miles south and over a width of about 2 miles from the sea shore, on the west, to the hills, on the east.

The Ereater portion of the damage was observed in the alluvial. area of the town adjacent to the river bank.

\section{Foundation failures}

A notable feature of the earthquake was the lack of foundation failures. Settlement of timber piles was noted in some houses。

No damage to sewer and stormwater drains or water reticulation pipe work was notified。

Some damarge to concrete floor slabs in tharr structures was obsorved and cracking in the filling was obvious where the embanlements had slumped towards the river.

One notable example of amplification of sround motion due to poor subsoil was observed. One of a row of houses built on an alluvial terrace was constructed over a sulley which had been filled with silt sluicings。 The house was apparently well constructed, of timber frime with plastered brickwork veneer. The vibritions were sufciciently intense to move larce sections of the veneer bodily by up to two inches. The foundation beam was undamaged and there was no foundation settlement. Repairs would involve the rebuilding of most of the veneer and the redecoration of the interior. Other houses of similar construction on the same terrace were virtually unmarked.

\section{Types of failure}

Maximum damage to commercial buildings occurred from the east-west shaking. This was mainly due to the fact that most of the older more earthquake vulnerable buildings were built with their long axis north-south. 
A comparison of these buildings with the few built in an east-west direction indicited thit the east-west component of the shaking was probably greater thin the north-south, even thouch the epicentre was nearer the north than the east.

Brickwork parapets on the north-south walls collipsed in many cases, and in most cuses surfored some lateral displacoment.

There was some evilence of hammering of timber ceiling joists causing lateral displacement of purapetis.

Cintilever ver:ndahs which were inadequately held back to the roof structure drooped in many cases, and in some cases pulled the whole street wall forward into a dingerous state.

Some bricli walls built in an east-west direction suffered from vertical tonsile cracking and in most cases horizontil shear failure in the mortar jointinir was evident。

Very little cracking in concrete structures was observed even in the older structures. When cracking did occur this was cenerally at construction joints or areas of under reinforcement.

\section{Types of building}

$\therefore$ number of the structures in the commercial area were built in the late $1300^{\prime} \mathrm{s}$. The majority of the bujldings in this zone however were constructed in the 1925 - 1930 period.

These buildiniss were built basically of unreinforced brickwork exterior walls with timber floor joists and roof trusses and plaster lined timber partitions.

Buildins with concrete frames built during the later period, and the majority of those erected since the introduction of the N.Z. Model Building By-liws s:ffered only minor damage to brick infill panels.

ieinforced blockwork and concrete work, at present under construction showed no apparent sign of structural damage.

\section{Secondary damage}

Non-structuril damage occurred in most buildings.

In ceneral wall papers were ripped and torn, plastered walls were cracked and glazing was broken. Water damatge from broken pipes was minimal and there was no recorded evidence of gas or electrical explosions.

Several cases of large relative movements between building elements were observed. Cover flashings between parapets and box gutters were found jammed between the gutter and the parapet. A relative movement of at least 4 inches would be required to achieve this.

\section{After shocks}

Damage to cracked brickwork joints was in some cases greater following the subsequent earth tremors than during the initial shock。

Cracks caused by the initial tremor were found to have been extended by the subsequent shocks. 


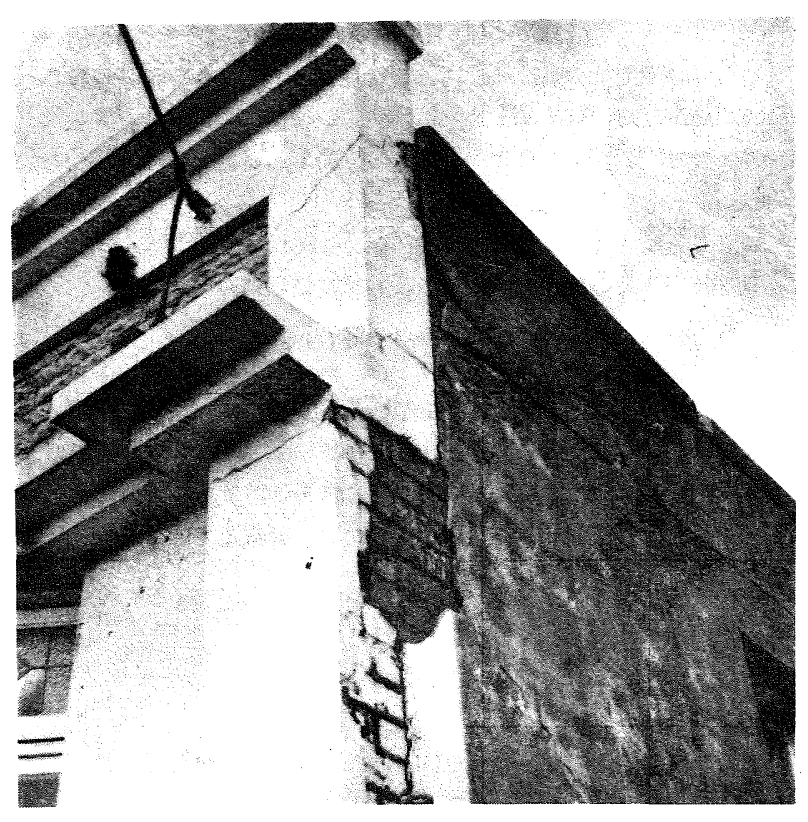

Fig. 1. Typical Damage to

Brickwork parapets.

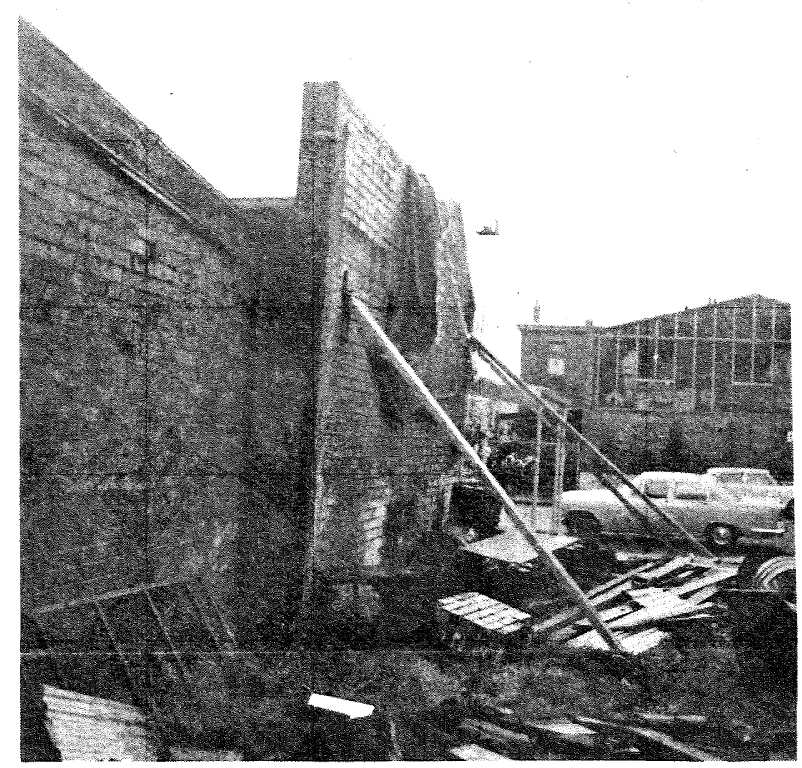

W.C. 739

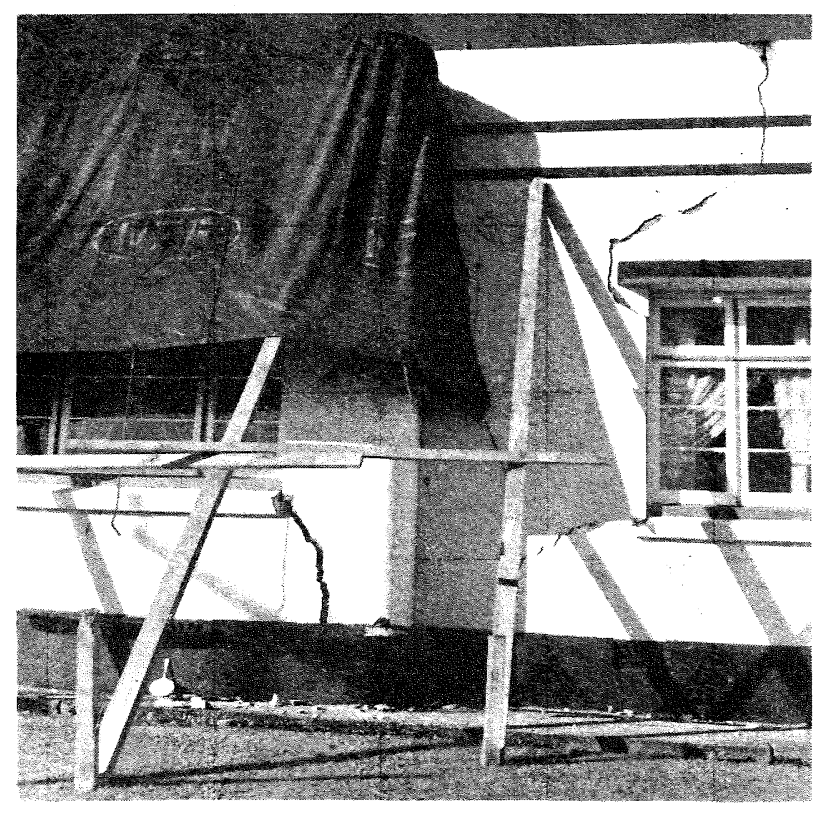

Fig. 2. Timber framed brick veneer house built on poor subsoil

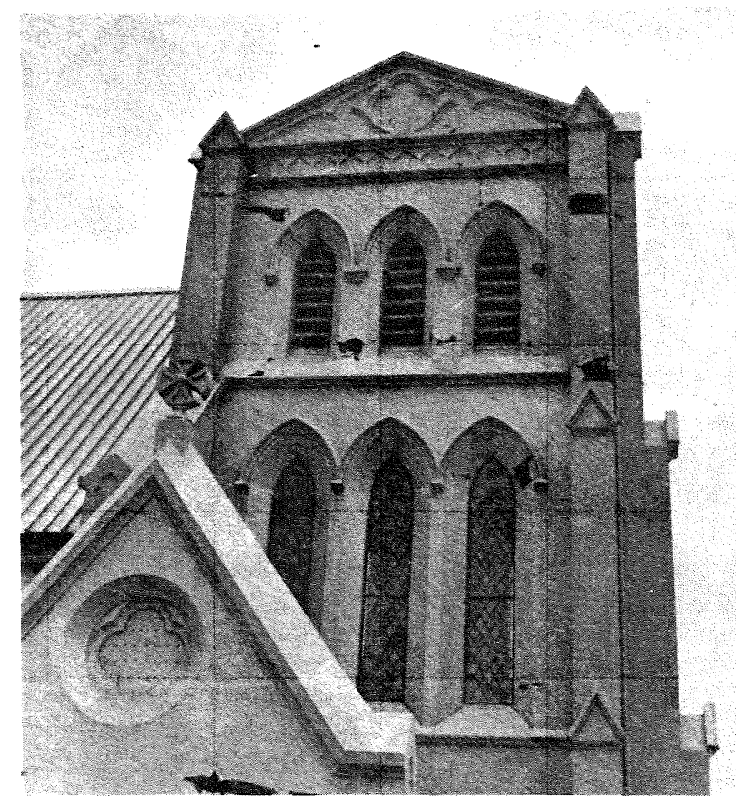

Fig. 4. Cracking to unreinforced brickwork of bell-tower. 


\section{Particular damage}

One concrete wall panel structure erected recently suffered extensive damage where the triangular shape of the high walls pulled away from the supporting roof structure due to inadequate fixing at that point。

The most prevalent failure pattern was the cracking of the brickwork of street wall parapets away from the two side wall parapets.

In one two storey building, of the typical brick wall - timber floor and roof construction, the west wall (street wall) separated from the north and south return walls and moved outwards, a maximum of $1 \frac{1}{4}$ " at the centre of the building, at the first floor level. In this case inspection showed that the original wire fixings securing the timber wall plate to the brickwork had Iong since disappeared。

\section{Conclusions}

The great majority of the damage occurred to old buildings which had been designed with no thought for seismic resistance. In most cases their present condition was poor, compared to their original state. (Metal fixings had rusted, lime mortar had rotted out, cracks were present from previous earthquakes, etc.). The damage which occurred was in most cases obvious and inevitable. Perhaps the surprising fact was that such buildings could withstand the earthquake without collapse.

Buildings designed to conform to the $\mathrm{N} . \mathrm{Z}$. Model Building By-laws suffered only insignificant damage. Damage in such buildings as did occur could generally be traced to a fault in workmanship or detailing. 